\title{
ANALISIS KESALAHAN SISWA KELAS X IPA.2 SMA NEGERI 1 UJUNGBATU DALAM MENYELESAIKAN SOAL PADA MATERI PERTIDAKSAMAAN RASIONAL DAN IRASIONAL
}

\author{
Wiwik Setiyaningsih \\ Pendidikan Matematika, Univeristas Riau \\ Email : setianingsihwiwik@yahoo.co.id
}

\begin{abstract}
Abstrak. Penelitian ini bertujuan untuk menganalisis kesalahan yang dilakukan siswa berdasarkan analisis kesalahan menurut Soedjadi yang terdiri dari kesalahan fakta, konsep, prinsip, dan kesalahan operasi pada materi pertidaksamaan rasional dan irasional satu variabel. Jenis penelitian yang dilakukan adalah penelitian deskriptif kualitatif yang menggambarkan keadaan/gejala yang sebenarnya dari siswa dalam menyelesaikan soal. Subjek penelitian adalah siswa kelas X IPA.2 SMA Negeri 1 Ujungbatu tahun pelajaran 2017/2018 yang berjumlah 36 siswa terdiri dari 13 siswa laki-laki dan 23 siswa perempuan dengan kemampuan yang heterogen. Instrumen penelitian yang digunakan adalah tes hasil belajar. Tes hasil belajar yang diberikan terdiri dari 5 soal yang telah divalidasi oleh 2 validator. Tes hasil belajar ini digunakan untuk mengumpulkan data hasil belajar siswa pada materi pertidaksamaan rasional dan irasional satu variabel yang selanjutnya akan dianalisis dan dilakukan wawancara kepada siswa untuk mendapatkan informasi mengenai kesalahan siswa dalam menyelesaikan soal. Berdasarkan analisis kesalahan yang dilakukan siswa, dapat disimpulkan bahwa sebagian besar kesalahan yang dilakukan siswa adalah kesalahan operasi dan kesalahan fakta pada soal penyelesaian masalah. Kesalahankesalahan yang dilakukan siswa disebabkan karena tidak teliti dalam menyelesaikan soal dan siswa kurang memahami operasi aljabar.
\end{abstract}

Kata Kunci: Fakta, Konsep, Prinsip, Operasi

\section{PENDAHULUAN}

Pendidikan merupakan aspek yang sangat penting dalam kehidupan manusia, karena pada dasarnya pendidikan merupakan suatu proses yang mampu membantu manusia dalam mengembangkan dirinya sehingga mampu menghadapi setiap perubahan yang terjadi. Pendidikan juga merupakan sarana vital dalam proses pengembangan sumber daya manusia dalam rangka pencapaian tujuan nasional. Tujuan pendidikan Indonesia dalam Undang-Undang Nomor 20 Tahun 2003 tentang Sistem Pendidikan Nasional adalah untuk mencetak generasi bangsa yang beriman dan bertakwa, berbudi luhur, cerdas, dan kreatif. Tujuan pendidikan tersebut kemudian diimplementasikan dalam kurikulum yang diselanjutnya diterapkan pada pembelajaran di sekolah.

Matematika sebagai salah satu mata pelajaran yang diajarkan dari sekolah dasar hingga perguruan tinggi memegang peranan yang cukup besar bagi keberhasilan belajar siswa. Melalui pembelajaran matematika, siswa diharapkan dapat menumbuhkan kemampuan berpikir logis, kritis, sistematis, cermat, efektif, dan efisien dalam memecahkan masalah. Namun, pembelajaran matematika di sekolah sering kali dianggap sulit dan membosankan. Salah satu penyebabnya adalah karena matematika memiliki objek yang abstrak. Sebagian besar yang dipelajari dalam matematika adalah angka atau bilangan yang secara nyata tidak ada atau merupakan hasil pemikiran otak manusia. Selain itu, materi yang dibelajarkan dalam matematika sering kali berkaitan antara materi yang satu dengan yang lainnya. Untuk mempelajari materi baru, diperlukan pengetahuan dan pemahaman yang memadai tentang satu atau lebih materi yang telah dipelajari sebelumnya. Oleh karena itu, guru harus lebih memperhatikan ketercapaian tujuan pembelajaran pada setiap materi yang dipelajari.

Ketercapaian tujuan pembelajaran dapat dilihat dari keberhasilan siswa dalam menyelesaikan soal matematika. Untuk itu, diperlukan adanya evaluasi atau tes hasil belajar siswa. Dari hasil evaluasi ini, dapat diketahui sejauh mana keberhasilan proses belajar mengajar dan letak kesalahan siswa dalam mengerjakan soal. Kesalahan siswa dalam mengerjakan soal bisa menjadi petunjuk sejauh mana penguasaan siswa terhadap materi pembelajaran. Dari kesalahan yang dilakukan siswa, dapat diteliti dan dikaji lebih lanjut mengenai sumber kesalahan siswa dengan menganalisis akar permasalahan yang menjadi penyebab kesalahan yang dilakukan siswa. Hal ini dilakukan agar guru mengetahui kekurangan dan kelemahan selama pembelajaran untuk selanjutnya dilakukan tindakan perbaikan agar kesalahan yang sama tidak terulang lagi.

Salah satu materi yang diajarkan pada kelas $\mathrm{X}$ SMA kurikulum 2013 adalah Pertidaksamaan rasional dan irasional satu variabel. Pertidaksamaan rasional dan 
irasional satu variabel merupakan salah satu materi aljabar yang diajarkan di SMA yang melibatkan prinsip penyelesaian tertentu dan banyak menggunakan aturan operasi aljabar. Pada materi ini, biasanya siswa hanya mengerjakan soal secara prosedural sesuai contoh yang diberikan guru tanpa memahami dengan baik prinsip penyelesaian pertidaksamaan rasional dan irasional dan penerapannya dalam penyelesaian masalah. Hal ini menyebabkan siswa banyak melakukan kesalahan dalam menyelesaikan soal. Berdasarkan hal tersebut, peneliti menganalisis kesalahan yang dilakukan siswa dalam menyelesaikan soal pada materi pertidaksamaan rasional dan irasional.

Menurut Seodjadi (2000), kesalahan siswa dalam menyelesaikan soal matematika dapat dibedakan menjadi kesalahan fakta, kesalahan konsep, kesalahan prinsip, dan kesalahan operasi. Kesalahan fakta adalah kesalahan dalam menuliskan konvensi-konvensi yang dinyatakan dengan simbol-simbol matematika, contohnya kesalahan dalam membuat model matematika dari suatu permasalahan, kesalahan dalam menginterpretasikan hasil yang didapat, dan kesalahan dalam menuliskan simbol-simbol matematika. Kesalahan konsep adalah kekeliruan dalam menggolongkan atau mengklarifikasikan sekumpulan objek. Konsep yang dimaksud dalam matematika dapat berupa definisi. Contoh kesalahan konsep antara lain kesalahan dalam menggolongkan apakah suatu relasi merupakan suatu fungsi. Kesalahan prinsip adalah kekeliruan dalam beberapa fakta atau beberapa konsep. Contoh kesalahan prinsip antara lain kesalahan dalam menggunakan rumus atau teorema serta kesalahan dalam menggunakan prinsip-prinsip sebelumnya. Sedangkan kesalahan operasi adalah kekeliruan dalam pengerjaan hitung, pengerjaan aljabar, dan pengerjaan matematika yang lain. Contoh kesalahan operasi adalah kesalahan dalam menjumlahkan, mengurangkan, dan kesalahan dalam operasi matematika lainnya.

\section{METODE}

Jenis penelitian ini adalah penelitian deskriptif kualitatif. Penelitian deskriptif kualitatif merupakan salah satu jenis penelitian kualitatif yang bertujuan untuk menggambarkan atau menganalisis suatu hasil penelitian. Penelitian ini mendeskripsikan analisis kesalahan hasil jawaban siswa dalam menyelesaikan 5 soal materi pertidaksamaan rasional dan irasional. Subjek penelitian adalah siswa kelas X IPA.2 SMA Negeri 1 Ujungbatu tahun pelajaran 2017/2018 yang terdiri dari 36 siswa dengan 13 siswa laki-laki dan 23 siswa perempuan. Instrumen penelitian yang digunakan adalah tes hasil belajar yang terdiri dari 5 soal pada materi pertidaksamaan rasional dan irasional satu variabel yang digunakan untuk mengumpulkan data jawaban siswa dalam menyelesaikan soal. Selain tes hasil belajar, peneliti juga melakukan wawancara untuk mendapatkan informasi mengenai kesalahan siswa dalam menyelesaikan soal. Teknik pengumpulan data yang digunakan adalah teknik tes tertulis. Hasil jawaban siswa dianalisis secara kualitatif dengan melihat jenis kesalahan yang dilakukan siswa pada setiap indikator pada materi pertidaksamaan rasional dan irasional satu variabel.

\section{HASIL DAN PEMBAHASAN}

Pelaksanaan tes dilakukan pada hari Selasa, 29 Agustus 2017. Setelah siswa selesai mengerjakan 5 soal pada materi pertidaksamaan rasional dan irasional, kemudian peneliti melakukan analisis terhadap hasil jawaban siswa dalam menyelesaikan soal. Soal yang diberikan terdiri dari tiga soal berdasarkan Kompetensi Dasar (KD) 3.2 Menjelaskan dan menentukan penyelesaian pertidaksamaan rasional dan irasional satu variabel dan dua soal berdasarkan KD 4.2 Menyelesaikan masalah yang berkaitan dengan pertidaksamaan rasional dan irasional satu variabel.

Adapun kesalahan-kesalahan yang dilakukan siswa pada setiap indikator soal pada KD 3.2 yaitu:

Indikator 1 dan 2: Menentukan himpunan penyelesaian pertidaksamaan rasional bentuk linear dan kuadrat

Soal:

1. Tentukan himpunan penyelesaian pertidaksamaan
a) $\frac{5 x-10}{x+2}>0$.
b) $\frac{x^{2}-7 x+6}{x^{2}-x-6} \leq 0$.

Pada indikator ini, peneliti melihat bahwa sebagian besar siswa telah memahami langkah-langkah penyelesaian pertidaksamaan rasional dengan baik. Namun, masih ada beberapa siswa yang menjawab secara prosedural, tanpa memahami dengan baik langkah penyelesaian pertidaksamaan rasional. Kesalahan yang dilakukan siswa pada indikator ini umumnya adalah kesalahan operasi. Berikut contoh kesalahan operasi yang dilakukan siswa. 


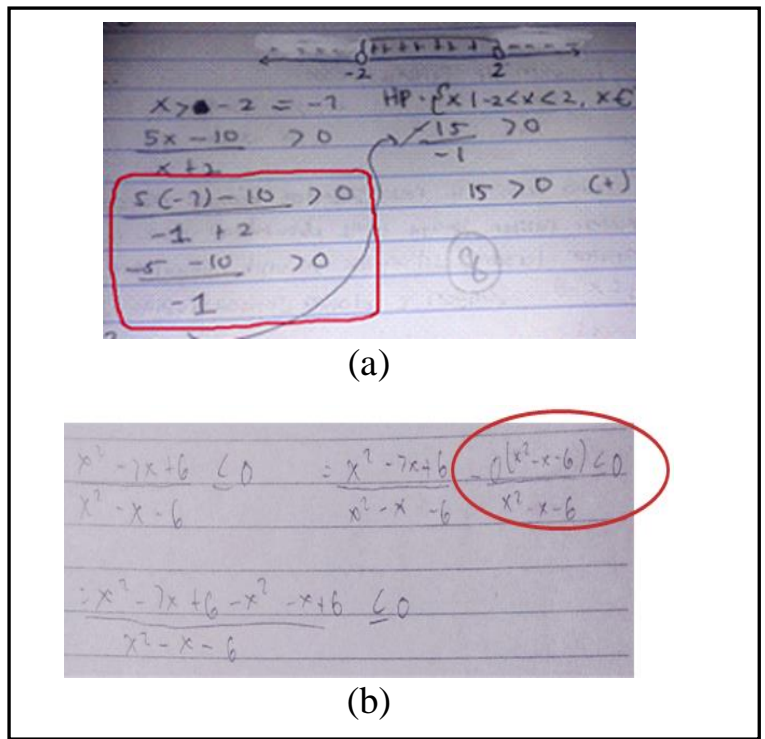

Gambar 1. Contoh Kesalahan Operasi dan Prinsip yang dilakukan Siswa pada Indikator 1 dan 2

Kesalahan yang dilakukan siswa pada Gambar 1 (a) adalah kesalahan operasi, dimana siswa salah menjumlahkan pada penyebut pertidaksamaan rasional, sehingga salah dalam menentukan tanda (+/-) setiap interval. Hal ini mengakibatkan siswa salah dalam menentukan himpunan penyelesaian pertidaksamaannya. Dalam hal ini, siswa kurang teliti dalam mengerjakan soal tes. Gambar 1 (b) menunjukkan kesalahan prinsip dan kesalahan operasi yang dilakukan siswa. Siswa hanya mengerjakan soal secara prosedural tanpa memahami dengan baik prinsip penyelesaian pertidaksamaan rasional. Seharusnya siswa menyamakan penyebut jika ruas kanan pertidaksamaan adalah bilangan selain nol, sedangkan jika ruas kanan pertidaksamaan adalah nol, siswa tidak perlu menyamakan penyebut di ruas kiri. namun tidak memahami dengan baik langkah penyelesaian pertidaksamaan rasional. Selain itu, kesalahan operasi juga tampak pada gambar (b), dimana siswa salah dalam mengalikan nol dengan $x^{2}-x-6$. Siswa tidak memahami dengan baik pengerjaan operasi aljabar.

Indikator 3. Menentukan himpunan penyelesaian pertidaksamaan irasional

Soal:

3. Tentukan himpunan penyelesaian pertidaksamaan $\sqrt{6 x-4}<\sqrt{2 x+8}$.

Pada indikator ini, sebagian besar siswa telah melakukan penyelesaian pertidaksamaan irasional dengan baik. Namun, masih banyak siswa yang tidak memperhatikan sifat bilangan bentuk akar dalam penyelesaiannya, yaitu setiap bilangan di dalam akar harus $\geq 0$. Dalam proses pembelajaran, guru perlu menekankan bahwa sifat bilangan bentuk akar sangat berpengaruh pada himpunan penyelesaian pertidaksamaan irasional. Kesalahan lain yang tampak pada indikator ini adalah kesalahan fakta dan kesalahan prinsip. Contoh kesalahan fakta dan kesalahan prinsip yang dilakukan siswa adalah sebagai berikut.

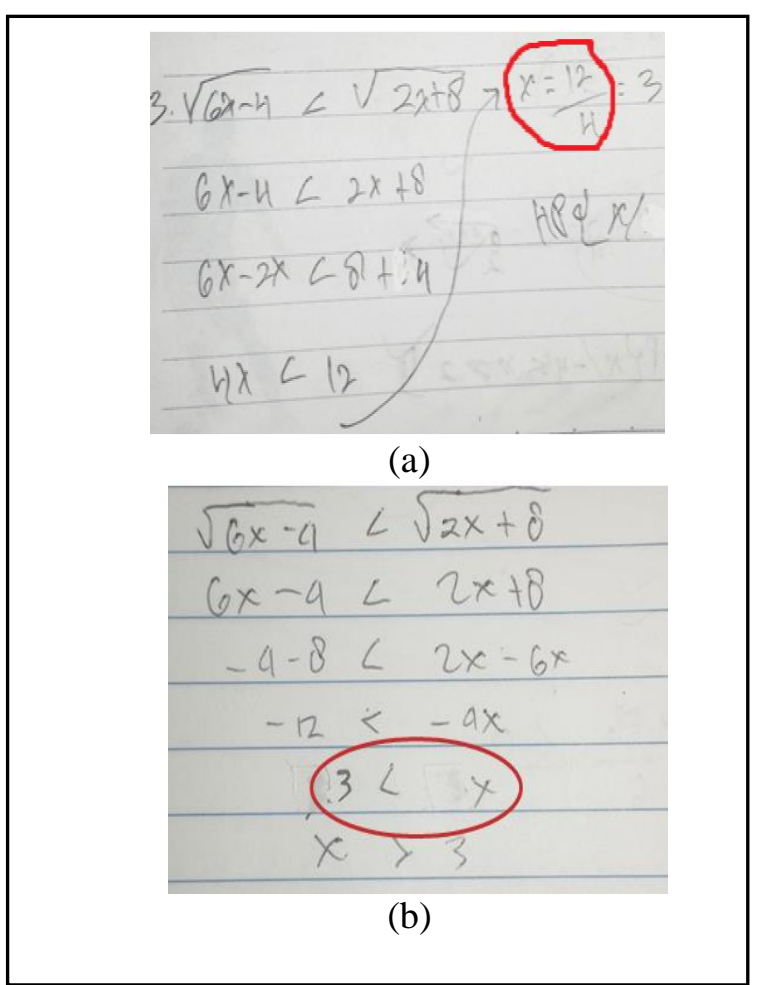

Gambar 2. Contoh kesalahan fakta dan prinsip yang dilakukan siswa pada Indikator 3

Pada Gambar 2 (a), siswa melakukan kesalahan fakta, dimana siswa salah dalam menuliskan tanda pertidaksamaan menjadi tanda "sama dengan". Sedangkan pada gambar 2 (b), siswa salah dalam melakukan prinsip operasi pada pertidaksamaan. Tanda pertidaksamaan akan berubah jika kedua ruas pada pertidaksamaan dikali bilangan negatif. Dalam hal ini, kedua ruas dikali $-1 / 4$, maka tanda pertidaksamaan seharusnya berubah. Namun, siswa tidak merubah tanda pertidaksamaan tersebut. Sedangkan kesalahan yang dilakukan siswa pada indikator soal KD 4.2 adalah sebagai berikut. 
Indikator 4. Menyelesaikan permasalahan yang berkaitan dengan pertidaksamaan rasional

\section{Soal:}

2. Siswa kelas XII SMK Teknologi berhasil memproduksi sebuah sepeda motor rakitan. Biaya yang dibutuhkan untuk memproduksi sepeda motor rakitan tersebut sebanyak $x$ unit dinyatakan oleh persamaan $C(x)=$ $\frac{16 x-8}{x+1}$ dengan $C$ dalam jutaan rupiah. Jika biaya maksimal yang dapat disediakan SMK Teknologi untuk memproduksi sepeda motor rakitan tersebut adalah Rp.12.000.000, maka tentukan banyaknya sepeda motor rakitan yang dapat diproduksi siswa SMK Teknologi.

Kesalahan siswa yang tampak pada indikator ini adalah kesalahan fakta dan kesalahan operasi. Berikut contoh kesalahan fakta dan kesalahan operasi yang dilakukan siswa pada indikator 4.

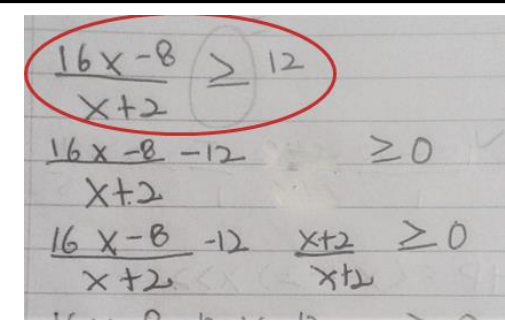

(a)

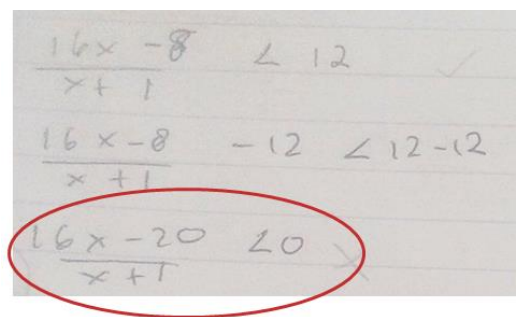

(b)

Gambar 3. Contoh Kesalahan Fakta dan Operasi yang dilakukan Siswa pada Indikator 4

Gambar 3 (a) menunjukkan kesalahan fakta yang dilakukan siswa, yaitu siswa salah dalam membuat model matematika dari permasalahan. Model matematika yang tepat seharusnya adalah $\frac{16 x-8}{x+1} \leq 12$, namun siswa menuliskan $\frac{16 x-8}{x+2} \geq 12$. Siswa melakukan kesalahan dalam menentukan tanda pertidaksamaan yang tepat dari permasalahan. Selain itu, siswa juga salah menuliskan $x+1$ pada penyebut rasional menjadi $x+2$. Hal ini menunjukkan bahwa siswa kurang teliti dalam mengerjakan soal tes. Pada Gambar 3 (b), siswa melakukan kesalahan operasi dan kesalahan fakta. Kesalahan fakta yang dilakukan adalah siswa kurang tepat dalam menentukan tanda pertidaksamaan dari permasalahan. Tanda pertidaksamaan yang tepat adalah $\leq$, namun siswa menulis $<$. Hal ini akan berpengaruh pada himpunan penyelesaian yang didapat siswa. Sedangkan kesalahan operasi yang dilakukan siswa adalah kesalahan dalam mengoperasikan $\frac{16 x-8}{x+1}$ dengan -12 . Siswa seharusnya mengubah -12 menjadi bentuk pecahan dengan menyamakan penyebut terlebih dahulu agar dapat dijumlahkan dengan $\frac{16 x-8}{x+1}$. Hal ini menunjukkan bahwa siswa tidak memahami dengan baik aturan operasi hitung pecahan bentuk aljabar.

Indikator 5. Menyelesaikan permasalahan yang berkaitan dengan pertidaksamaan irasional

\section{Soal:}

4. Sebuah sepeda motor melaju selama $t$ menit dengan panjang lintasan $S$ (dalam kilometer) ditentukan oleh persamaan $S(t)=$ $\sqrt{3 t+9}$. Jika sepeda motor tersebut menempuh panjang lintasan sekurangkurangnya $6 \mathrm{~km}$, maka tentukanlah waktu tempuh sepeda motor tersebut.

Kesalahan yang dilakukan siswa pada indikator ini adalah kesalahan fakta dan kesalahan operasi. Berikut contoh kesalahan yang dilakukan siswa pada indikator 5 .

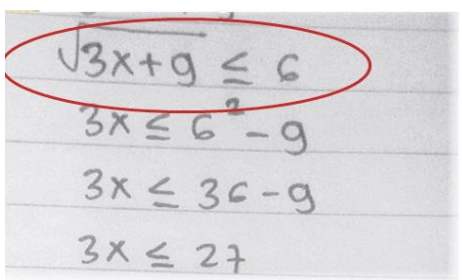

(a)

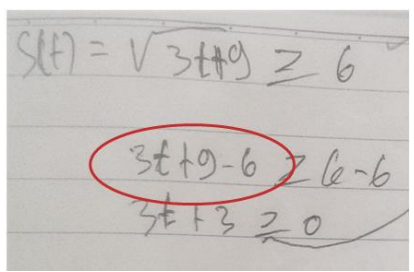

(b)

Gambar 4. Contoh Kesalahan yang dilakukan siswa pada Indikator 5 
Pada Gambar 4 (a), siswa melakukan kesalahan fakta sama seperti pada indikator 4, yaitu siswa salah dalam menentukan tanda pertidaksamaan yang tepat berdasarkan permasalahan. Model matematika yang tepat berdasarkan permasalahan adalah $\sqrt{3 t+9} \geq 6$, namun siswa menuliskan $\sqrt{3 x+9} \leq 6$. Pada Gambar 4 (b), siswa melakukan kesalahan operasi. Siswa melupakan tanda akar pada $3 t+9$. Hal ini menunjukkan bahwa siswa kurang teliti dalam mengerjakan soal tes.

Berdasarkan uraian kesalahan siswa diatas, dapat disimpulkan bahwa sebagian besar kesalahan siswa disebabkan oleh siswa masih kurang memahami aturan pengoperasian aljabar dan kurang teliti dalam mengerjakan soal tes. Dalam hal ini, sebaiknya guru mengingatkan kembali dan lebih memahamkan siswa mengenai aturan pengoperasian aljabar. Selain itu, guru harus menekankan kepada siswa agar lebih teliti dalam mengerjakan soal. Pada indikator pertidaksamaan irasional, peneliti melihat bahwa sebagian besar siswa telah memahami dengan baik penyelesaian peridaksamaan irasional. Namun, peneliti menemukan bahwa masih banyak siswa yang tidak memperhatikan sifat bilangan bentuk akar, yaitu setiap bilangan di dalam akar harus $\geq 0$. Dalam hal ini, sebaiknya guru lebih menekankan kepada siswa mengenai sifat bilangan bentuk akar, bahwa sifat bilangan bentuk akar ini sangat berpengaruh pada himpunan penyelesaian pertidaksamaan irasional.

\section{SIMPULAN}

Berdasarkan hasil penelitian dan pembahasan dapat disimpulkan bahwa dalam mengerjakan soal tes materi pertidaksamaan rasional dan irasional, siswa kelas X IPA.2 SMA Negeri 1 Ujungbatu tahun pelajaran 2017/2018 umumnya melakukan kesalahan operasi dan kesalahan fakta pada soal penyelesaian masalah. Kesalahan-kesalahan yang dilakukan siswa disebabkan karena tidak teliti dalam menyelesaikan soal dan kurang memahami aturan operasi aljabar.

\section{REKOMENDASI}

Berdasarkan faktor penyebab dari kesalahan yang dilakukan siswa, maka peneliti mengajukan rekomendasi yang berhubungan analisis kesalahan siswa pada materi pertidaksamaan rasional dan irasional, yaitu guru sebaiknya memastikan bahwa siswa telah memahami dengan baik materi awal yang dibutuhkan untuk membangun pengetahuan awal siswa dengan melakukan apersepsi dengan baik. Selain itu, sebaiknya siswa lebih banyak diberikan latihan berupa penyelesaian soal untuk meningkatkan kemampuan siswa menyelesaikan soal pada materi pertidaksamaan rasional dan irasional satu variabel.

\section{DAFTAR PUSTAKA}

Kemendikbud. (2014). Permendikbud No 59/2014: Kurikulum 2013 Sekolah Menengah Atas/Madrasah Aliyah. Kemendikbud. Jakarta

Kemendikbud. (2016). Permendikbud No 24/2016: Kompetensi Inti dan Kompetensi Dasar Pelajaran pada Kurikulum 2013. Kemendikbud. Jakarta

Purwanto. (2009). Evaluasi Hasil Belajar. Pustaka Belajar. Yogyakarta

R. Soedjadi. (2000). Kiat Pendidikan Matematika di Indonesia Konstatasi Keadaan Masa Kini Menuju Harapan Masa Depan. Dikjen Dikti Depdiknas. Jakarta

Sugiyono. (2008). Metode Penelitian Pendidikan. Alfabeta. Bandung 